\title{
The Tunisian Economics' Situations after the Revolution of Arab Spring
}

\section{1}

\author{
Foued Sabbagh ${ }^{1}$ \\ ${ }^{1}$ Faculty of Law and Economic and Politic Sciences of Sousse - University of Sousse \\ Correspondence: Mr. Foued Sabbagh, Ph.D, Master Finance and Development 2010, from the university of Sousse \\ - Faculty of Law and economics' and politics Sciences of Sousse and International Economic Researcher. E-mail: \\ fouedsabbagh_2010@yahoo.fr
}

Received: September 4, 2021

Accepted: October 26, $2021 \quad$ Online Published: October 31, 2021

doi:10.5430/bmr.v10n3p15

URL: https://doi.org/10.5430/bmr.v10n3p15

\begin{abstract}
The Tunisian economic facts after the so-called the Arab spring or social revolution have been marketed by numerous fluctuations and radical changes in the general situation of the management of the administrative affairs of the country. The most prominent of these facts, including the series of chaotic sit-ins and the political and security instability that has increased from 2011 to 2018, note in particular the emergence of the phenomenon of terrorism and assassinations. These negative results are too the expensive cost of the Tunisian national economy, which has been directed, affected by all vital sectors of the country's economy, especially the tourism, trade and investment sectors. In addition, the increase in excessive wages during the first three years following the revolution and the increasing number of random sit-ins that led to the cessation of the production in the Gafsa phosphate mine and the failure to work for most of the public servants represented negative factors that led to a decline in productivity and an increase in the financial and trade deficit. Thus, the budget deficit and the accumulation of indebtedness represent the main obstacle to achieving social and economic stability.
\end{abstract}

Keywords: economics' situations, positives, negatives, causes of recession, Tunisian revolution

\section{Introduction}

The economic transition from 1987 to 2010 was marked by remarkable achievements in the development of infrastructure and economic development of Tunisia, with international recognition of the most important international institutions, led by the World Bank, the international monetary fund and institutions of notation. These victories represent a significant gain for future generations, including major government projects such as hospitals, universities and recreational places such as the project of Lac in Tunis capital. Tunisia has also made considerable progress in implementing comprehensive rehabilitation programs for the Tunisian economy while continuing to implement the development plans adopted since independence in 1956 in coordination with international financial institutions. However, with the accumulation of popular discontent resulting from poverty and degradation linked to marginalization, high unemployment rates and the deterioration of purchasing power, the process of development reform has shifted to chaos and uncertainty. The post-revolution period has been marked by a series of rescue reforms resulting from the deterioration of social and economic conditions due to the indifference of the old regime to the basic needs of certain poor and needy categories, including the improvement of conditions of life and employment. The radical reforms of the Tunisian economy were launched at the end of 2011 under a transitional government that suffers from weakness and fragilities in the country's internal and external affairs due to the accumulation of financial and trade deficits. However, foreign financial assistance in the form of grants, financial assistance and long-term loans from the World Bank and the international monetary funds has not been used properly and appropriate for dealing with accumulated crises. Since the release of the Arab Spring Revolution in Tunisia in 2011, the Tunisian political and economic scene was pilot events and developments, which have been observed never for one century. During a short time and after seven years of this revolution, which reversed the last regime, six governments were named. Consequently, these political disturbances and governmental instability have contributed to the deterioration of the economic situations and social instability. As that they were for the random sit-ins and chaos in the popular districts or the general strikes under the supervision of the General Tunisian Union of work have an important role in the accumulation of the crises and the disturbance of the production of phosphate of the mining area of Gafsa and the 
coalfield of salt, and the country side where is the oil and the events of the town of camor and other chaotic events during seven years since the social revolution. In addition the terrorist operations, in particular at the time of so-called the Troika, which led to political assassinations and terrorist attacks against the foreigners, they completely paralyzed the sector of tourism and they have negatively affected the financial incomes of the reserve of the Central Bank of Tunisia until the end of 2015. The results were disastrous for the exchange of Tunisian Dinar against the basket of the foreign currencies, in particular, the Euro and the Dollar, where the Tunisian Dinar has triplet against these currencies and it entered to the phase of the crisis of exchange. In addition, the random of recruitments in the public service during the period from 2011 to 2014, the enormous wage increase with the increasing inactivity at work, the lack of productivity contributed of the accumulation of this crisis and the overload of the public balance of payments to additional expenditure. The post-revolution period has been marked by a series of rescue reforms resulting from the deterioration of social and economic conditions due to the indifference of the old regime to the basic needs of certain poor and needy categories, including the improvement of conditions of life and employment. The radical reforms of the Tunisian economy were launched at the end of 2011 under a transitional government that suffers from weakness and fragilities in the country's internal and external affairs due to the accumulation of financial and trade deficits. However, foreign financial assistance in the form of grants, financial assistance and long-term loans from the World Bank and the international monetary funds have not been used properly and appropriate for dealing with accumulated crises. In addition, the depletion of public financial resources contributed to the compensation of the general amnesty and the victims of the old regime or the huge increase in salaries and random assignments in the civil service between 2011 and 2013 in the general situation of the Tunisian national economy. The factors of the phenomenon of violence, terrorism and assassinations also contributed to the entry into the Tunisian country in a climate of chaos that almost led to direct foreign interference in the internal affairs by the maintenance of its economic missions, political, strategic or diplomatic. As a result, the Troika government failed miserably and was finally overthrown by popular pressure in all Tunisian cities and the withdrawal of Islamic movements from the government scene in late 2013. As a result, a government was formed to get the Tunisian economy out of the economic gulf while maintaining social peace, security and political stability in early 2014. The transition period ended after the 2015 national elections, after which Tunisia adopted new development programs and new economic policies based mainly on liberalization and openness while strengthening the status of the private sector in the Tunisian economy. In general, the Tunisian economic situations after the Arab spring revolution of 2011 were pilot many advantages and disadvantages, including a focus on the reducing of the fiscal deficit and achieving an economic growth rate into 2012 of $3.99 \%$, and to improve the living conditions through wage increases and reducing the rate of unemployment. However, the disadvantages had a more serious and major impact on the financial and banking economy, which is fragile as a whole. As he had recourse to the borrowing from the institutions of Bretton Woods or the world financial markets to refund the domestic debt and the exemption of the wages or the indebtedness to recover the preceding debts. These factors have accumulated, the budget deficit has increased and the exacerbation of the debt have complicated the things, in particular the trade and economic with the permanent partners such as the European Union and the United States of America.

What was the root causes of the economic recession and budget deficit after the so-called Arab spring in Tunisia in 2011?. And what are the advantages and disadvantages of the Tunisian macroeconomic system during the post-revolutionary?

\section{Impact of the Sit-Ins and Terrorism on the Tunisian National Economy}

There is not any doubt that the events, which followed the Tunisian revolution in 2011, constitute a dangerous precedent for Tunisian national security and the economic and the development assets of Tunisia. The subversive and the disturbing sit-ins also had direct negative effects on the investment and the trade. Despite of the fact that the democracy is the construction and the establishment of the next of the future generations in a civilized way but sometimes becomes destructive and subversive if the criticism crosses was exceeded the red lines whereas the conflicts of the Tunisian parties between them on the power and the political and financial influence, become an internal war to sabotage the national economy. In addition, the opening of many seats of the parties of opposition and political bodies under cover of the constitution, under governmental financing by subsidies of the State budget, overall constitutes a negative factor, which weights the account public balance of payments and grafts it by additional internal debts. After the revolution, Tunisia became commercial financed the political side more than three times what it was before the revolution, in particular to extract the wages from certain persons in charge for political or constitutional bodies or others such as the commission for truth and dignity. A rising succeeded the bases of popular parties of the major parties, which also receive financial subsidies from the government. However, this environment of the complex parties formed an incubator of the political conflicts which increased the number of sit-ins and if the majority of them were under the direction of some political parties which seek political and economic instability. All these sit-ins had a direct impact on 
the national economy, blocking the production and reducing the investment opportunities and confidence in the financial and commercial markets. The lower rate of the economic growth rate of $1.1 \%$ in 2015 and 2016 reduced the creation of the new employment opportunities and the finance public underwent losses and accumulated the additional deficits over the last years. In general, the sit-ins are represented a source of concern for the government because of its direct impact on the Tunisian economic situations. However, the popular demonstrations or the working strikes are legitimate and must be regulated in accordance with the law because they are completely required claims of the human rights, including the employment and the reduction of the rate of unemployment, the improvement of the purchasing power and the reduction of the food prices, the supply of the adequate basic services to the citizens and the improvement of the level of income per capita. But the so-called chaotic sit-ins poisoned by the incentive of the party and the acts of sabotage and burning, and they attacks counter the public installations and the centers of security are criminal and there have negative effects and more damaging that the popular protests and the working strikes, and at all levels of the national economy. The growing feelings of social dissatisfaction, poverty, unemployment and the popular dissatisfaction with the management administrative of the government or the lack of feeling of wellbeing and happiness lead certain Tunisian citizens to be directed towards illegal immigration and to fall into the trap of the terrorism traffickers and to be transformed into a tool of international crime influenced on Tunisia's tourist or investment destination. As all the world's countries, Tunisia has been a victim of the terrorism; which has caused huge of enormous financial losses, particularly on the tourist sector and the foreign direct investments. The effects of terrorism have been devastating of the Tunisian national economy, particularly in 2013 and 2015, including the political assassinations, the events of Sousse and Bardo. Among these economic losses caused by terrorism, there the losses on the gross national income, the decline of the economic growth rate, the suppression of the direct foreign investment by intimidating and the exclusion of the investors, the disturbances of the production and the lack of confidence general with regard to the performance of the government, the increase in the rate of unemployment in particular in the sectors affected by terrorism. In this context, a study was concluded by Subhayu Bandyopadhy and Todd Sandler (2014) that the effects of terrorism on the international trade for a small open economy become more influential on the factor of offer because the terrorism has reduced the labor recruitment and lead to involve loss of the national income because of the outflows of capital and also the policy of the fight against the terrorism has an active role in the economy. Therefore, the strong reduction of the foreign investments nets and the commercial losses are cause for serious economic damage. The factor of terrorism is represented by disruption of the industrial and tourism production and may be accompanied by a reduction of the foreign aid with a deterioration of the national sovereign rating, which causes rising the rule of unemployment and the problem of illegal immigration.

\section{Lack of Productivity and Wage Increases}

During the first three years after the revolution of 2011 in Tunisia, the public finance suffered a significant loss their financial resources. It acted for the file of the victim's compensation of the last regime and the recruitments overloads in the public service the greatest share allocated with these issues. Thus, in addition to the rise in the prices of the foodstuffs in 2010 and the entry of the country in period of social and economic crisis, the wages have been increased in an unforeseen way, mainly compared to the economic situation. The study George Joffé (2011) concluded that the sudden climbing of the prices of foodstuffs at the end of 2010 caused the disgust of the public to a result of the repression and the deterioration of the purchasing power. Consequently, the series of events since 2011 to 2014 has affected the national economy where the budget deficit in 2014 was highest with $-9.12 \%$ of the GDP. The political instability and the disruption of the production by successive events constituted a direct impact on the trade, finance and the investment. The country entered the phase of inactivity and the lack of productivity. Moreover, of the lack of success of progress in the renewal of the model and the methods of development and in the implementation of the structural reforms, including tax. Therefore, the failure to follow the neoliberal economic reform and of not dismantling the old system of central control, focusing on previous models of development caused a slow development and overall rehabilitation in all sectors of the economy. According to the essay of Adel Malik and Bassem Awadallah (2013) on the economy of Arab spring, that the State in these economies reaching for all the productive sectors when it comes to the necessities of the life, such as food, energy, employment, housing and other public services and often the primary education and the last side to satisfy the fundamental needs. Generally the increases in the public expenditure and the payments of the wages are exchanges with the fall of the rate/rhythm of the technological changes and to fill the numerical ditch and the decline of the vital productive sectors such as agriculture and industry and in particular the financial receipts in foreign currencies of the tourist sector and the sale of traditional products are represented as a whole factors influential negatively on the economic situation of Tunisia. As a result, the production has decreased and the capacity of competitiveness has decreased from where trade has been affected and the productivity has declined and the debt has accumulated. Once of the principal problems with which Tunisia is currently confronted is the 
domestic debt, the deficit of the trade balance and the budget deficit due to the fragility of the financial and fiscal system and certain business escape from the extraction of taxes and refunding of the payments of the bank loans. In addition, the process of liberalization of the banking sector has not fully realized and no privatization has been carried out in the sector of education and the higher education, to which a large part of the budget is allocated. Due to the bad performance of the government and the overlapping of the economic capacity by the political power, and in particular the lack of development of the private sector and the fight against the financial corruption and the tax evasion and the fight against bleaching from the capital and the money with the excessive increase in the wages for certain nonproductive sectors such as education, security and the general lack of productivity decreased the rate of economic growth and the fall of the Tunisian Dinar compared to the Euro and to the Dollar and the Tunisian national economy entered in phase of recession and a negative prospect for the future negatively has affected the investment and the debt.

\section{Macro-Economic Tunisian after the Arab Spring Revolution: Advantages and Disadvantages}

Despite of the difficult economic, social and political situation of the post-revolution period in Tunisia, the new government experienced a certain economic revival especially at the end of 2012. The government of the Troika has adopted a group of experts of the Tunisian economy at the head of the ministry for Finances and the Central Bank of Tunisia. Where some structural and administrative reforms were achieved and a good economic growth of 3.99\% in 2012. However, the achievement and the radical change towards economic decentralization and the development are rapidly transformed into economic recession, especially after the excessive increase in the wages and the heaviness of the finance public with compensations for the people victims of Last regime and the overburdening of the public debt on the social funds. Despite of the advantages obtained by the ministry of Finance through the renewal of the system of covering and the structural administrative reform and stimulate the liberalization of the investments and the exchanges by the lifting of certain customs duties to facilitate trade and to increase the rate of economic growth. However, the negative points were dominant on the economic plan, in particular the emergence of the phenomenon of terrorism, the assassinations and the rise of the popular protests, which has affected the security situation and thus political instability where many governments to be changed during a very short period of time what has affected the investment and economic stability. Which led the country into a phase of economic recession, in particular during the second quarter of 2015 and the economic situations remained fluctuating between the growth and the decline and macro-economic instability at the long period between 2011-2016. Despite all these negative factors economy detached Tunisia has not fallen into a banking crisis or a bankruptcy in favor of cohesion throughout this period and it started to reach this stage by constant decisions of the Central Bank of Tunisia to reduce inflation and to increase the interest rate, especially by the beginning of the implementation of the thirteenth quinquennial development plan 2016-2020.

\subsection{Advantages}

The most important positive aspects observed by the Tunisian economy during the period following the revolution of 2011 can be summarized as follows:

1) The Central Bank has eased its monetary policy since the beginning of 2011 with the aim of liberating the monetary and banking economy and supporting the economy activity and the financial system. The Central Bank of Tunisia also continued the effective monetary policy, which is based on a flexible management of the principal interest rate and the stability of reserves of exchange in foreign currencies.

2) Economic and commercial cooperation and diversification of the relations with certain countries in order to attract more foreign direct investments.

3) To develop the all private sector while maintaining financial and banking stability while gaining in confidence. Despite of these economic and social disruptions, Tunisia did not undergo a banking crisis or general bankruptcy.

4) A clear improvement in the indicators of absence of corruption and economic liberalization (statistical table 1) especially on the level of the index of liberalization of the corruption and tax liberalization and the liberalization of the climate of the businesses and the investment and the improvement of the monetary liberalization index, as for financial liberalization, it was stable to $30 \%$.

5) Continuation of the structural reform and the administrative regulation to follow the rate/rhythm of the international standards while using modern technologies to fill the numerical ditch. Consequently, improvement of the level of human development.

6) The reduction of rate of poverty, in particular inside the cities of the country, and the adoption of the social protection and coverage policy social while reducing the public expenditure through an austerity policy in 2014. 
7) The most important realization is the plan of development 2016-2020 or so-called the international conference sister investment to support the Tunisian economy and to ensure stability and prosperity. This conference concentrates on five axes, in particular the realization of a total development such as the development of the infrastructures of the roads and the public equipment, the investment and the liberalization of the trade and reducing the trade balance deficit, the good governorship and the continuation of the administrative reform and the fight against the financial corruption, the passage of an economy at low cost to an economic pole with increased competitiveness in the local and the world markets, the human development, the social solidarity and the reduction of unemployment, the adoption of the concept of the green economy which is considered as the pillar of the global development.

\subsection{Disadvantages}

Due to the accumulation of the internal problems of popular protests and political conflicts, the macroeconomics was damaged clearly during the last period, in particular from 2014 to 2017. A certain number of the negative factors contributed to the deterioration of the economic situations, in particular one notes:

1) During the year 2011, Tunisia's macro-economic fundamentals deteriorated and the economic growth registered a negative decline was $-1.91 \%$, as it did not exceed $1.1 \%$ between 2015 and 2016 (Statistical table 2).

2) The fragility of the banking structure and the weak performance of the financial sector due of the impact of the non-performing loans in the bank's capital and the lack of adequate supervision of the banking and financial sector and the lack of a good governance banking.

3) The financial deficit of the Tunisian budget increased $-8.78 \%$ in 2016 led to an increasing in the debt, such as the stocks of external debt (\% of the GNI) was $69.49 \%$ in 2016 with the continuously increased expenses of the IMF (INT, USD Current).

4) The cost of terrorism and a tent on Tunisia's economy so that caused huge financial and commercial and economic losses, including losses in gross national income, retard economic growth, fight against foreign direct investment, damaged tourism and traditional industries significantly and the total deficit sector of the trade and financial balance.

5) Moreover due to the sit-in escalation in a chaotic and random way with the failure of the majority of employees in the public sector work and an increase in spending on education, especially on the wire public security to disable development plans and curb economic growth with a lack of progress in the implementation of economic and sector reforms of structural programs, which caused a serious economic recession.

6) The loss of confidence in investments in Tunisia, with the paralysis of the private sector and the burden of public finances and the balance payments burden resulting from excessive wage increases, which led to an increase in debt for recovering domestic debt or closing the deficit of social funds with delays in the payment of wages of employees in public jobs.

7) The fall of the direct investments following the loss of confidence for the foreign investors to invest in Tunisia, because of the political and security instability and the deterioration of the indicators of the international sovereign notation of Tunisia by the agencies of the international notations of the debts and also because of the financial corruption of the money bleaching and tax evasion.

8) The exchange trade was affected, where the trade (\% of the GDP) decreased to $89.98 \%$ in 2016 . Consequence, the trade balance was affected what by the nature suffers from a continuous deficit.

9) The rises in the prices of the foodstuffs, inflation and unemployment have directly affected consumption and the savings.

10) The collapse of the Tunisian Dinar against the Euro and the Dollar that could lead to a currency crisis.

11) The risk of a decline in the general stock of the Central Reserve of the foreign currencies and the accumulation of the debt, in particular with the refunding of loans deadlines which could lead to a crisis of the sovereign debt.

Seven years after the Tunisian Arab Spring Revolution in 2011, the microeconomics and the macroeconomics of Tunisia continue to deteriorate due to the several internal and external factors. The majority of the private companies were damaged and low profitability reflects negatively on the production and the consumption. Also the weakness of the productivity, the capacity of competitiveness and the support of the private sector. On the other hand the macro-economy has been affected by the slowdown of the administrative and economic structural reforms and thus of 
the fragility of the financial and banking sector and the fall of the investments with the use of indebtedness to extract a last debt or to recover the wages that have been increased inefficiently.

\section{Conclusion}

This article aims to analyze the Tunisian economic situation after the 2011 social revolution and to study the root causes of the general economic recession between 2015 and 2018. According to the statistical indicators used in the methodology of analysis of previous economic events, especially between 2011 and 2013, most shows that there is a crisis in the general economic situation, so that events have worsened compared to the period before the revolution. Most economic indicators indicate the accumulation of the budget deficit in a bottom-up format. The economic growth fell to a low of $1.1 \%$ between 2015 and 2016, it was reduced compared to 2008 by $4.23 \%$. The total reserve of the Central Bank of Tunisia has decreased the marked increase in the external debt and in particular the expenses of the international monetary funds in US Dollars, with regard to the indicators against corruption and good governance, economic, monetary, trade, investment and financial liberalization has not improved much, but has remained stable. Generally, economic and social events in Tunisia between 2011 and 2018 were influenced by many internal and external factors, including the cost of terrorism, which weighed heavily on the Tunisian economy, the sit-in that chaotic hampered production, lack of productivity, and excessive increases in productivity. The downgrading of Tunisia's overall credit rating by global rating agencies has led to a loss of confidence by foreign investors in Tunisia and a decrease in exports has resulted in a decrease in the foreign exchange reserves of the Central Bank of Tunisia. The factors of political instability have also contributed to the deterioration of most economic indicators, mainly because of the global interdependence of political and economic events in the management of the country's internal affairs. Despite the many positive reforms of the macroeconomic system, the negative results put more of total gross national income, which affected general production and reduced productivity, which had a negative impact on local consumption, leading to higher prices, and increased inflation. In addition, savings and investments have declined, leading to a sharp decline in tax revenues and thus a financial and trade deficit. Between the beginning of 2015 and 2018, economic development was limited to the establishment of infrastructure for roads, railways and marine facilities, and no significant developments were recorded during this period. The economic growth has fluctuated, trade has been very weak and foreign currency hedging has been weak, resulting in the launch of government bonds in international financial markets to bust the reserves of the Central Bank of Tunisia.

\section{References}

African Development Bank Group. (2012). "Tunisie - African Economic Outlook”, Perspectives économiques en Afrique. BAFD, OCDE, PNUD, CEA.

Bandyopadhyay, S., \& Sandler, T. (2014). The effects of terrorism on trade: a factor supply approach. Federal Reserve Bank of St. Louis Review, 96(3), 229-241.

Bandyopadhyay, S., Sandler, T., \& Younas, J. (2015). The Toll of Terrorism: Terrorists not only exact a direct human cost, they can cause innumerable economic problems too. Finance \& Development, 52(002).

Joffé, G. (2011). The Arab spring in north Africa: origins and prospects. The Journal of North African Studies, 16(4), 507-532. https://doi.org/10.1080/13629387.2011.630881

Malik, A., \& Awadallah, B. (2013). The economics of the Arab Spring. World Development, 45, 296-313. https://doi.org/10.1016/j.worlddev.2012.12.015

Mazarei, A., \& Tokhir, M. (2015). Four Years After the Spring. Finance \& Development, (June), 55-57.

Sabbagh, F. (2017). The Study of Economics Tunisian Situation (Edition Neel and Fourat. Arabic version) (March 2018).

Trape, P., \& Kaouther, A. (2016). "Tunisie - African Economic Outlook”, Perspectives économiques en Afrique. BAFD, OCDE, PNUD, CEA. 


\section{Appendix}

Table 1. The indicators of the absence of corruption and economic liberalization from 2008 to 2016

\begin{tabular}{|c|c|c|c|c|c|c|c|c|c|c|c|}
\hline 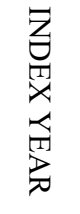 & 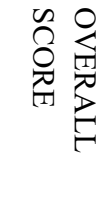 & 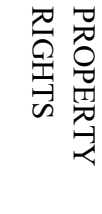 & 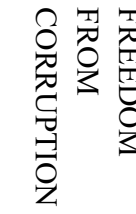 & 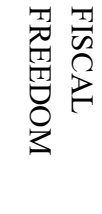 & 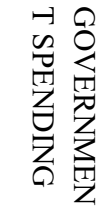 & 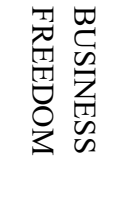 & 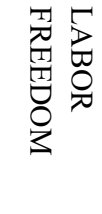 & 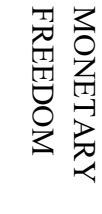 & 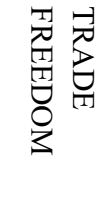 & 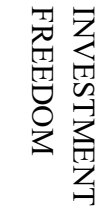 & 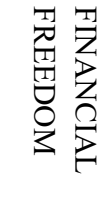 \\
\hline 2008 & 60.1 & 50.0 & 46.0 & 76.4 & 77.1 & 80.1 & 62.3 & 77.6 & 71.8 & 30.0 & 30.0 \\
\hline 2009 & 58.0 & 50.0 & 42.0 & 76.5 & 78.3 & 81.6 & 60.1 & 78.4 & 53.0 & 30.0 & 30.0 \\
\hline 2010 & 58.9 & 50.0 & 44.0 & 74.4 & 78.5 & 80.2 & 67.4 & 76.5 & 53.5 & 35.0 & 30.0 \\
\hline 2011 & 58.5 & 50.0 & 42.0 & 73.7 & 77.6 & 80.2 & 65.7 & 77.3 & 53.5 & 35.0 & 30.0 \\
\hline 2012 & 58.6 & 40.0 & 43.0 & 74.8 & 71.5 & 82.9 & 74.1 & 76.9 & 58.1 & 35.0 & 30.0 \\
\hline 2013 & 57.0 & 40.0 & 38.0 & 74.5 & 63.7 & 82.8 & 70.1 & 77.8 & 58.1 & 35.0 & 30.0 \\
\hline 2014 & 57.3 & 40.0 & 39.2 & 74.3 & 63.8 & 80.7 & 72.6 & 75.9 & 61.8 & 35.0 & 30.0 \\
\hline 2015 & 57.7 & 40.0 & 41.0 & 74.3 & 70.8 & 81.2 & 69.1 & 74.8 & 61.2 & 35.0 & 30.0 \\
\hline 2016 & 57.6 & 40.0 & 40.0 & 74.0 & 73.4 & 81.3 & & & & & \\
\hline
\end{tabular}

Source: The Heritage Foundation (Index of Economic Freedom).

Table 2. The most important Tunisian economic indicators from 2008 to 2016

\begin{tabular}{ccccccc}
\hline $\begin{array}{c}\text { Indicator } \\
\text { Name }\end{array}$ & $\begin{array}{c}\text { IMF charges } \\
\text { (INT, current } \\
\text { US\$) }\end{array}$ & $\begin{array}{c}\text { External debt } \\
\text { stocks }(\% \text { of } \\
\text { GNI) }\end{array}$ & $\begin{array}{c}\text { Total reserves } \\
\text { (includes gold, } \\
\text { current US\$) }\end{array}$ & $\begin{array}{c}\text { GDP growth } \\
\text { (annual \%) }\end{array}$ & $\begin{array}{c}\text { Trade (\% of GDP) } \\
\text { Current account balance } \\
\text { (\% of GDP) }\end{array}$ \\
\hline 2008 & 432000 & 50,6129774 & 9038905431 & 4,23777684 & 114,354832 & $-3,814931475$ \\
2009 & 984000 & 54,9234497 & $1,1294 \mathrm{E}+10$ & 3,04344895 & 93,0168788 & $-2,839145092$ \\
2010 & 1344000 & 53,5254522 & 9764263623 & 3,51060864 & 104,149109 & $-4,777295831$ \\
2011 & 460000 & 51,8708585 & 7785306752 & $-1,91717768$ & 104,529075 & $-7,390748694$ \\
2012 & 125000 & 58,5574189 & 8717830233 & 3,99766608 & 106,531077 & $-8,261645343$ \\
2013 & 1176000 & 58,0709962 & 7550027746 & 2,87475429 & 103,449905 & $-8,386102982$ \\
2014 & 7509000 & 57,4606291 & 7498011535 & 2,82315958 & 100,920287 & $-9,121188903$ \\
2015 & 12227000 & 64,8676563 & 7559201857 & 1,14940839 & 91,0501534 & $-8,920319784$ \\
2016 & 20167000 & 69,498949 & 6137077538 & 1,1697691 & 89,9858102 & $-8,782784264$
\end{tabular}

Source: World Development Indicators, World Bank.

\section{Copyrights}

Copyright for this article is retained by the author(s), with first publication rights granted to the journal.

This is an open-access article distributed under the terms and conditions of the Creative Commons Attribution license (http://creativecommons.org/licenses/by/4.0/). 